\title{
Cyanobacterial defense mechanisms against foreign DNA transfer and their impact on genetic engineering
}

\author{
Karina Stucken*†, Robin Koch ${ }^{\dagger}$, Tal Dagan ${ }^{\dagger}$ \\ Institute of Genomic Microbiology, Heinrich-Heine University of Düsseldorf, Düsseldorf, Germany. \\ $\dagger$ Present address: Genomic Microbiology Group, Institute of Microbiology, Christian-Albrechts-University of Kiel, Kiel, Germany
}

\section{SUMMARY}

Cyanobacteria display a large diversity of cellular forms ranging from unicellular to complex multicellular filaments or aggregates. Species in the group present a wide range of metabolic characteristics including the fixation of atmospheric nitrogen, resistance to extreme environments, production of hydrogen, secondary metabolites and exopolysaccharides. These characteristics led to the growing interest in cyanobacteria across the fields of ecology, evolution, cell biology and biotechnology. The number of available cyanobacterial genome sequences has increased considerably in recent years, with more than 140 fully sequenced genomes to date. Genetic engineering of cyanobacteria is widely applied to the model unicellular strains Synechocystis sp. PCC 6803 and Synechococcus elongatus PCC 7942. However the establishment of transformation protocols in many other cyanobacterial strains is challenging. One obstacle to the development of these novel model organisms is that many species have doubling times of $48 \mathrm{~h}$ or more, much longer than the bacterial models $E$. coli or $B$. subtilis. Furthermore, cyanobacterial defense mechanisms against foreign DNA pose a physical and biochemical barrier to DNA insertion in most strains. Here we review the various barriers to DNA uptake in the context of lateral gene transfer among microbes and the various mechanisms for DNA acquisition within the prokaryotic domain. Understanding the cyanobacterial defense mechanisms is expected to assist in the development and establishment of novel transformation protocols that are specifically suitable for this group.

Key words: Cyanobacteria, Genetic engineering, Defense mechanism, Restriction-modification.

\section{2.. INTRODUCTION}

Cyanobacteria carry out oxygenic photosynthesis as their main source of energy. Due to their low nutritional requirements, cyanobacteria are primary producers in the oceans and take a significant part in the oxygen and carbon cycles (Carpenter and Romans 1991, Partensky et al., 1999). Diazotrophic cyanobacteria also play an important role in the global nitrogen budget (Großkopf and LaRoche 2012); several of those species are found in endosymbiosis with plants, supplying nitrogen derivatives to their host (e.g., $\mathrm{NH}_{3}$ ). Cyanobacteria are gradually becoming useful in various biotechnological applications (Abed et al., 2009, Ruffing 2011) such as the production of biofuels (Quintana et al., 2011, Jones and Mayfield 2012) and hydrogen (Masukawa et al., 2012). Secondary metabolites of cyanobacterial origin are explored for their utility in novel drug design (Kufryk et al., 2002, Clerico et al., 2007). Cyanobacteria are monophyletic yet they are highly diverse in their phenotypic and genotypic characteristics, ranging from unicellular to filamentous cell differentiating types.

Genetic engineering of cyanobacteria is widely applied to the model unicellular strains Synechocystis sp. PCC 6803 (heretofore Synechocystis) and Synechococcus elongatus PCC 7942 (heretofore S. elongatus) where genetic manipulation techniques as well as genome sequences are available (Kumar 1962, Bazin 1968) and the typical growth rate is relatively fast ( $>1$ division per day). These strains are utilized as a model system for photosynthesis, type IV microbial motility, and circadian cycles research. Other suitable model organisms include the filamentous, heterocystous strains Anabaena sp. PCC 7120 and Nostoc punctiforme PCC 73102. Those are widely used to study cellular differentiation, mechanisms of nitrogen fixation, and cyanobacterial symbioses with plants.

The common methods for transferring foreign DNA into cyanobacteria are transformation, electroporation and conjugation. Transformation, or the uptake of naked DNA into a recipient genome, can occur by natural competence in some cyanobacterial strains and is the common method for transforming Synechocystis and S. elongatus (Kufryk et al., 2002, Clerico et al., 2007). DNA can also be transferred by electroporation to unicellular and filamentous cyanobacteria (Thiel and Poo 1989, Mermet-Bouvier et al., 1993). The transfer of circular DNA from E. coli to a diverse range of host bacteria via conjugation (Wolk et al., 1984) is the preferred method for gene transfer into cyanobacteria.

The biology and genomic repertoire of most cyanobacterial strains pose multiple difficulties to the existing genetic engineering approaches. For example, the slow growth rate of many strains reaching approximately 0.2 doublings per day (Lürling et al., 2013), is a drawback in genetic research. Furthermore, there are still many cyanobacterial species that are not transformable using the current methods of genetic manipulation, or for which the success rate of transformation/ conjugation is low. To overcome these barriers and develop better cyanobacterial-specific genetic engineering techniques, we have to understand the resistance mechanisms for DNA uptake that are utilized by species in this phylum.

\section{BARRIERS TO TRANSFER OF FOREIGN DNA INTO CYANO- BACTERIA}

Experimental evidence for microbial mating in cyanobacteria is dated back to the early 1960's where the mixing of two 
Anacystis nidulans strains (aka S. elongatus) resistant to different antibiotics gave rise to a double resistant strain (Kumar 1962, Bazin 1968). Transformation of natural competent S. elongatus was demonstrated later on in 1970 (Shestakov and Than Khyen 1970). Transformation with exogenous DNA, either plasmid, intergeneric or interspecific has been successful in a few unicellular species, including Synechococcus sp. PCC 7002 (Stevens and Porter 1980), Synechocystis (Grigorieva and Shestakov 1982), Microcystis aeruginosa PCC 7806 (Dittmann et al., 1997) and Thermosynechococcus elongatus BP-1 (Onai et al., 2004), as well as the heterocystous cyanobacteria Nostoc muscorum and Anabaena tortulosa (Trehan and Sinha 1982) where reciprocal transformation has been exemplified. One of the main difficulties in establishing a genetic transfer system in cyanobacteria, particularly the filamentous strains, is the presence of various restriction-modification systems in these species. Successful transfer of foreign DNA into filamentous cyanobacteria was enabled only once the restriction barrier was discovered. However, even today, after years of research, genetic engineering of cyanobacteria is still a challenging task.

Restriction modification systems constitute a genetic barrier, which is the main but not the only barrier to DNA uptake in cyanobacteria. Further physical and functional barriers need to be taken into account for the establishment of successful genetic transfer systems in novel cyanobacterial model organisms. Physical barriers include the presence of extracellular nonspecific nucleases, the production of exopolysaccharides, and unknown mechanisms for natural competence. The functional barrier is determined by the ability of foreign DNA to replicate in the host, either from an autonomously replicative plasmid or by integration into the host genome. Here we review the various barriers to DNA uptake in the context of lateral gene transfer among microbes and the various mechanisms for DNA acquisition within the prokaryotic domain (for reviews see Thomas and Nielsen 2005; Popa and Dagan 2011).

\subsection{Physical barriers to DNA uptake}

\subsubsection{Natural competence}

In gram-negative bacteria, natural competence corresponds to the formation of type IV pili (T4P) that form the short type II secretion system (T2SS). The proteins involved in natural competence are homologs to the T4P pilin proteins. In addition to forming the structure and motor of the pili, these proteins assist the binding of exogenous DNA to the cell surface, its transport into the cytoplasm, the processing of DNA into a single strand, and the protection against restriction endonucleases (Chen and Dubnau 2004). The genetic components of natural competence in cyanobacteria are yet poorly understood, with the exception of pili biogenesis and twitching motility in Synechocystis.

The genome of Synechocystis encodes for more than 30 homologous genes to the T4P pil genes of Pseudomonas aeruginosa including the genes encoding for the structural protein PilA and for PilT, an ATPase putatively involved in generating the force for retraction movement of the pili (Okamoto and Ohmori 2002). Disruption of pilA, pilT and other pil-like genes affected both pili formation and natural competence, showing that the biogenesis of functional pili is required for twitching motility and natural competence in Synechocystis (Yoshihara et al., 2001, Bhaya et al., 2001). In addition, two genes with low similarity to the $\operatorname{com} A E$ and comFA competence genes of Bacillus were identified and their disruption affects competence in Synechocystis (Yoshihara et al., 2001, Okamoto and Ohmori 2002, Nakasugi et al., 2006). The application of comparative genomics did not reveal further competence genes, probably due to the low sequence similarity with known competence genes, and the lack of clear operon structure in cyanobacterial genomes. Homologs to T4P genes were described in two other naturally competent cyanobacteria T. elongatus (Iwai et al., 2004) and M. aeruginosa PCC 7806 (Nakasugi and Neilan 2005). In M. aeruginosa PCC 7806 pili-like structures were detected by electron microscopy (Nakasugi and Neilan 2005). The M. aeruginosa PCC 7806 PilT protein sequence differs from that of Synechocystis and cannot complement a Synechocystis pilT mutant (Nakasugi et al., 2007). pilT knockouts of $M$. aeruginosa were not reported and whether T4P genes are involved in natural competence in Microcystis remains unknown.

Given the major role of T4P in various microbial motility mechanisms and the abundance of motile cyanobacteria, either by gliding, twitching or swimming, it is reasonable to assume that other functional T4P structures are yet to be discovered. Although alternative gliding mechanisms exist, for example by slime secretion through a pore complex as in some filamentous cyanobacteria (Hoiczyk and Baumeister 1998), hormogonia motility may still require T4P. Hormogonia are short filaments produced by some species of heterocystous cyanobacteria (subsections IV and V). These act as infecting agents in symbiotic cyanobacteria and as dispersal/reproduction units in non-symbiotic cyanobacteria (Rippka et al., 1979, Meeks and Elhai 2002). Pili structures were observed in hormogonia from Nostoc punctiforme while they were absent from vegetative cells (Duggan et al., 2007). Disruption of pil-like genes of $N$. punctiforme showed that they have a role in symbiotic competence (the ability of hormogonia to infect plant cells) but whether they are involved in motility is unclear since wild type hormogonia are not always motile. Increased expression of PilQ in N. punctiforme hormogonia during infection also supports the putative role of Pil proteins in symbiotic competence (Klint et al., 2006). If hormogonia indeed produce a functional $\mathrm{T} 4 \mathrm{P}$, then natural competence could be studied in hormogonia-enriched cultures. Elucidating the mechanisms of genetic competence in hormogonia developing cyanobacteria whose genome sequences are available, could assist in the prediction of natural competence in those.

\subsubsection{The exopolysaccharide layer}

Exopolysaccharides (EPS) are produced and secreted by a wide range of bacteria and are involved in diverse functions that range from resistance to desiccation (Mazor et al., 1996) and environmental stresses (De Philippis et al., 2011), cell adhesion, aggregation and biofilm formation (Sutherland 2001, Flemming and Wingender 2010), as well as gliding motility (Hoiczyk 2000). Cyanobacterial cell walls are unique among bacteria, combining elements from gram -negative and- positive bacteria. The presence of an outer wall groups cyanobacteria within gram-negative bacteria; however, the thick peptidoglycan layer and its higher degree of crosslinking resembles that of gram-positives (Hoiczyk and Hansel 2000). The composition of cyanobacterial EPS differs from that 
of eubacteria by i) the presence of one or two uronic acids ii) a high level of hydrophobicity induced by functional groups such as acetyl groups, deoxysugars, fatty acids and peptides (Fattom and Shilo 1984, De Philippis et al., 2000) iii) ) the number of different monosaccharides (up to 13 in Chroococcus minutus B 41.79) (Fischer et al., 1997) and iv) the presence of sulfate groups commonly encountered in archaeal and eukaryotic EPS but rarely in eubacteria (Panoff et al., 1988, Fischer et al., 1997, Nicolaus et al., 1999, Pereira et al., 2009). The presence of uronic acids and sulfate groups confer on cyanobacterial EPS a negative charge, and a sticky state that contribute to efficient sequestering of cations, specifically those of heavy metals (De Philippis et al., 2011). In recent years, the heavy metal chelating ability of cyanobacterial EPS has been widely exploited for treatment of wastewater (De Philippis et al., 2011). These and further applications of the EPS in biotechnology have been thoroughly reviewed elsewhere (De Philippis and Vincenzini 1998, Pereira et al., 2009, Freitas et al., 2011, De Philippis et al., 2011). Cyanobacterial EPSs can be classified according to their arrangement at the cell surface in sheath, capsule and mucilage (also slime) (Figure 1A). However, the nomenclature of the different layers is somewhat misleading since there is no constant use of terms in the literature. In this review we will follow the terms used by Bertocchi et al. (1990), De Philippis and Vincenzini (1998), and Nicolaus et al. (1999).
The sheath is easily identified by light microscopy without staining as a thin translucent layer delineating the shape of the cyanobacterial cell, filament or aggregate. It is fibrillar in composition and more rigid than the capsule. The capsular polysaccharides (CPS) surround the sheath and vary extensively in their thickness among the different cyanobacteria. These are usually visible by negative staining (India ink) and can be detached from the filament by washing with hot water (Hough et al., 1952). The mucilage is normally secreted to the extracellular milieu as soluble released polysaccharide (RPS) but it may remain attached to the cell surface. All EPS layers can be visualized with alcian blue staining, which is a cationic dye (Ramus 1977).

The composition and amount of EPSs is heterogeneous among cyanobacteria and may be influenced by environmental conditions such as light intensity, temperature, culture medium, growth stage or nutrient availability (reviewed by De Philippis and Vincenzini, 1998, Pereira et al., 2009). Since these variations are strain-specific, they need to be considered if a decreased EPS production level is required previous to the application of a genetic manipulation. The CPS and RPS ratio vary among cyanobacterial isolates as well, where RBS is generally produced in lower quantities than CPS, exceptions are Oscillatoria and Scytonema hofmanni that produce 6-7 times more RPS than CPS (Nicolaus et al., 1999).
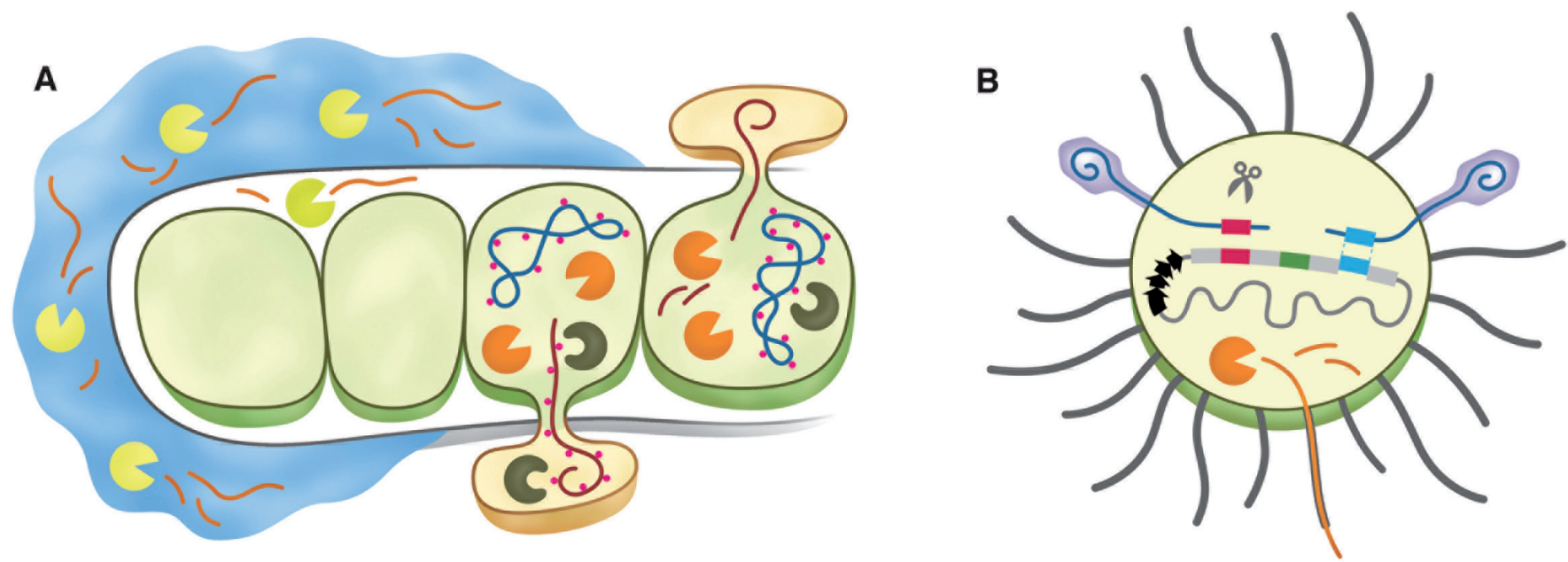

Figure 1. Barriers to transfer of foreign DNA into cyanobacteria. (A) A thick EPS layer composed of CPS (blue) and sheath enclosing cyanobacterial cells presents a physical barrier that may hinder DNA-cell and cell-cell contact. Extracellular nucleases (yellow pacmans) secreted by the host are embedded in the EPS matrix (sheath, capsule and slime) and degrade foreign DNA upon contact. If the physical EPS barrier is passed either by trichome breakage, enzymatic (e.g., some phages encode for polysaccharide lyases (Labrie et al., 2010)) or chemical lysis, or if it is thin enough to allow cell to cell contact, then foreign DNA can be transferred by conjugation (third and fourth cell in the left plot) or transduction. Restriction-Modification (RM) systems differentiate host DNA from foreign DNA trough methylation of host DNA (pink dots) by methyltransferases (MTases) (grey invaginated circles). Restriction endonucleases (REases) (orange pacmans) recognize and cleave unmethylated DNA acquired by either gene transfer system (third cell in the left plot). DNA degradation by RM systems can be avoided by premethylation of DNA with the enzymes known to be active in the host or by randomly premethylating DNA with dam or $d c m$ methylases (fourth cell in the left plot). (B) Development of type four pili (T4P) has been observed only in few natural competent unicellular cyanobacteria. DNA transferred by natural transformation is subject to degradation by RM systems. Transduction as a gene transfer mechanism in cyanobacteria has not been documented, but several cyanophages infecting unicellular and filamentous cyanobacteria have been described. Immunity against phage infection is given by the clustered regularly interspaced short palindromic repeat (CRISPR) systems (see text) composed of cas genes (black arrows), CRISPRs (grey boxes) and acquired spacers (colored boxes). If the nucleotide sequence of the incoming phage DNA is recognized with 100\% identity by one of the spacers (pink box), the CRIPSR complex will degrade the foreign DNA, exemplified by the scissors. Incoming and acquired DNA from former transduction events is shown as blue and green boxes, respectively. 
So far no correlation between the EPS amount and transformation success was documented. However, the EPS content described for several model cyanobacteria is considerably lower than that of environmental or extremophile cyanobacteria, raising the possibility that EPSs are a strong barrier for DNA uptake in cyanobacteria. For example, the CPS content of Anabaena sp. PCC 7120 is less than 1\% of its dry mass (Nicolaus et al., 1999), this can be also observed by using alcian blue stain, which only stain heterocyst polysaccharide and not the vegetative cells of the filament (Merino-Puerto et al., 2010). In contrast, the CPS production of the desert cyanobacteria Nostoc calcicola Gietler, strain 79WA01 can be as high as $70 \%$ of the cell biomass (Flaibani et al., 1989). Several unicellular subsection I cyanobacteria are described as sheathless (Rippka et al., 1979), but that does not imply that there is no EPS production in those strains, as polysaccharides can be also released into the extracellular matrix. Synechocystis produces $30 \mathrm{mg} \mathrm{L}^{-1}$ of RPS in 30 days (Panoff et al., 1988), and S. elongatus PCC 7942 can produce up to $462 \mathrm{mg} \mathrm{L}^{-1}$ in 21 days (Sangar and Dugan 1972), values that are similar to other unicellular cyanobacteria (De Philippis and Vincenzini 1998) and comparably lower than the RPS production of Cyanospira capsulata, which can reach $4 \mathrm{~g} \mathrm{~L}^{-1}$ in 31 days (Vincenzini et al., 1990). Cyanobacteria that are difficult to transform such as Fischerella muscicola and Chlorogloeopsis fritschii, produce large amounts of CPS corresponding to 15$30 \%$ of the total cell dry mass (Schader et al., 1982, Pritzer et al., 1989). Representatives of the Chrooccocidiopsis spp. are the only members of subsection II cyanobacteria for which a successful gene transfer has been reported (Billi et al 2001). These species produce thick EPS layers, however, it was shown that increased thickness of Chrooccocidiopsis spp. sheath did not affect conjugation efficiency. Nevertheless many other cyanobacteria produce large amounts of EPS, among those Phormidium sp., Anabaena WSAF, Anabaena torulosa (Nicolaus et al., 1999), Chroococcus minutus (Adhikary et al., 1986) and Mastigocladus luminosus (Gloaguen et al., 1999).

The EPSs composing the hard sheath and capsular slime around the cell form a physical barrier to DNA transfer. In addition to that, the slime is known to house metabolites such as the UV protective Scytonemin (Proteau et al., 1993) and non-covalently attached proteins of mostly unknown function, including nonspecific extracellular nucleases that degrade foreign DNA (Wolk and Kraus 1982, Soper and Reddy 1994, Takahashi et al., 1996). Reduction of EPS production by either optimizing growth conditions or establishing degradation protocols is expected to reduce the CPS layer thickness and help to overcome the physical barrier for DNA import. The enzymatic barrier could be lowered by washing the culture to remove possible nucleases. For example, an effective removal of nucleases has been achieved by increasing the $\mathrm{Mg}^{+2}$ concentration in the culture medium of Spirulina platensis where the reduction of $96-98 \%$ of intra and extracellular nuclease activity was observed (Cao et al., 1999). The reduction of EPSs previous to conjugation-based genetic manipulations could assist in increasing the cell surface area available for donor-recipient contact. Treatment procedures may include growing the cultures under agitation leading to the release of CPSs to the extracellular milieu. However, such treatment will not remove the sheaths which are strongly attached to the cell surface (Hoiczyk and Baumeister 1995). Other strategies include the use of media with a low concentration of saline sodium citrate (SSC) concentration (0.015 - $0.15 \mathrm{M})$ (Wolk and Kraus 1982), or pumping the cells out of the sheath using a syringe (Haitao and Xudong 2004). EPS degradation in thermophilic cyanobacteria can be also performed by washing with hot water $\left(>60{ }^{\circ} \mathrm{C}\right)$; however, this procedure requires a subsequent assessment of cell viability. Recently we described a successful conjugation enabling treatment of high-EPS containing cyanobacteria consisting of $1 \mathrm{~h}$ agitation of the cultures with concentrated $(0.5-1 \mathrm{M}) \mathrm{NaCl}$, followed by multiple washes with fresh culture media (Stucken et al., 2012). Additionally, DNA import into the cell using particle bombardment does not require previous treatment of the cells but is less efficient than conjugation (Stucken et al., 2012); this technique, based on high-pressure delivery of DNA coated gold or tungsten particles, is the standard method for organelle targeted transfection (Klein and Fitzpatrick-McElliot 1993).

\subsection{Genetic barriers}

DNA acquisition by lateral gene transfer (LGT) plays a major role in prokaryotic genome evolution (Doolittle 1999, Gogarten and Townsend 2005). Cyanobacterial genomes encode for diverse laterally transferred elements including transposases, phage integrases, insertion and repeated sequences (Frangeul et al., 2008, Elhai et al., 2008). LGT among cyanobacterial strains is frequent (Raymond et al., 2002, Mulkidjanian et al., 2006, Dagan et al., 2013) and has been shown to affect $66 \%$ of the cyanobacterial protein families (Dagan et al., 2013). Yet, the abundance of toxin-antitoxin systems that are carried on mobile elements (Van Melderen 2010) as well the mode of bacteriophage infection, led to the evolution of various defense mechanisms to discriminate self from foreign DNA (Thomas and Nielsen 2005, Popa and Dagan 2011, Vasu and Nagaraja 2013). Microbial immune systems against foreign DNA invasion include restriction-modification (RM) systems (Arber and Linn 1969) as well as the recently discovered clustered regularly interspaced short palindromic repeats (CRISPR) system (Sorek et al., 2013).

\subsubsection{Restriction-modification systems}

Restriction-Modification ( $\mathrm{RM}$ ) systems are the bestcharacterized defense mechanism against foreign DNA invasion in bacteria (Arber and Dussoix 1962, Vasu and Nagaraja 2013). Typical RM systems are composed of a restriction endonuclease (REase) and a cognate methyltransferase (MTase). The REase recognizes and cleaves unmodified DNA at a specific sequence motif. The MTase modifies DNA by methylation of cytosine and adenine residues within the REase recognition sequence so that the host DNA is protected from the REase activity (Figure 1A). RM systems are classified according to the recognition site, cleavage position, subunit composition, and cofactor requirements into four groups (types I-IV) (Roberts 2003). Since the discovery of RM systems about 50 years ago, almost 5,000 restriction endonucleases, representing more than 300 modes of activity have been discovered in bacterial and archaeal genomes, 66 of which are cyanobacterial. Most cyanobacterial restriction enzymes are classified as Type II systems with AvaII, AvaI and AsuII as the most frequent enzymes in the phylum (Lyra et al., 2000). Many RM systems, specifically restriction activities, have been detected in 
cyanobacteria, mostly within the filamentous forms (Wolk and Kraus 1982, Lyra et al., 2000) but also within unicellular representatives from the Microcystis and Cyanothece genera (Soper and Reddy 1994, Soper et al., 1996, Takahashi et al., 1996). Here we will discuss the role of RM systems as a defense mechanism against DNA transfer into cyanobacteria in the laboratory.

Restriction enzymes cleave only double stranded DNA. Thus, DNA acquired by natural transformation or conjugation that is imported into the cell as a single strand (Chen et al., 2005) should be immune to the RM system. However, REases can cleave single stranded DNA that is folded into a secondary structure if two identical restriction sites are transiently paired (Nishigaki et al., 1985), or even when only one restriction site is present (Horiuchi and Zinder 1975, Bischofberger et al., 1987). This implies that DNA acquired by either transfer mechanism can be subject to degradation by RM systems (Thiel and Poo 1989, Dittmann et al., 1997, Elhai et al., 1997). Consequently, the quantity and diversity of RM systems within the modified bacteria have a large impact on the choice of DNA transfer approach and the transformation success rate. For example, the presence of one unmethylated AvaII site within a plasmid vector reduced the transformation efficiency by 100 -fold in an electroporation experiment with Anabaena sp. strain M131 (Thiel and Poo 1989). Furthermore, the number of methylated AvaI, AvaII, and AvaIII restriction sites encoded within a plasmid is positively correlated with the efficiency of conjugal transfer in Anabaena sp. PCC 7120 (Elhai et al., 1997).

Strategies to circumvent the RM barrier include either the use of helper plasmids carrying cognate MTases for the REases encoded by the cyanobacteria (Thiel and Poo, 1989; Elhai et al., 1997) or deletion of the restriction sites from the foreign DNA (Wolk et al., 1984). Another alternative is the engineering of mutant strains that are devoid of REases, but this solution still requires cyanobacteria strains that are transformable (Iwai et al., 2004). The use of helper plasmids that encode a combination of MTases for AvaI, AvaII, and AvaIII sites led to successful gene transfer experiments in cyanobacteria from all five subsections (Summers et al., 1995, Billi et al., 2001, Tolonen et al., 2006, Stucken et al., 2012, Taton et al., 2012). This is probably because AvaI is widely distributed among cyanobacteria (Lyra et al., 2000). However, cyanobacterial strains express a wide variety of RM systems. Previous knowledge of the RM systems repertoire encoded by the cyanobacterium to be genetically modified is expected to assist in the design of specific helper plasmids that are devoid of recognized restriction sites or encode for a suitable MTase. Here we present the result of a computational prediction of RM systems encoded in 141 cyanobacterial strains. Homologs to known RM systems deposited in REBASE database (Roberts et al., 2010) were identified by protein sequence similarity. Coding sequences having $\geq 30 \%$ amino acid similarity to known REases and MTases were considered as functional homologs. A total of 1,541 REases and 7,212 MTases had homologs in at least one cyanobacterial genome. These correspond to 188 unique recognition sites (Figure 2). The most abundant recognition sequences are GATC (137 genomes) and CGATCG (93 genomes) that are degraded by type II REases. No homologs to type III REases were found grouping the currently available genomes. However, this could be also due to the paucity of type III REases in the REBASE database. Most Prochlorococcus and Synechococcus strains contain RM systems that recognize a limited range of motifs, with the exception of Synechococcus sp. PCC 6312
(15 motifs), Synechococcus sp. PCC 7002 (10 motifs), and Synechococcus sp. PCC 7336 (10 motifs). The largest restriction barriers seem to be present in filamentous cyanobacteria from Arthrospira (Spirulina) and Oscillatoria, unicellular Cyanothece and all Pleurocapsales strains. The largest recognition site diversity is found in the genomes of M. aeruginosa NIES-843 (40 motifs), Arthrospira maxima CS-328 (37 motifs), Calothrix sp. PCC 7103 (34 motifs) and Nodularia spumigena CCY9414 (28 motifs). A computational prediction of the restriction sites recognized by specific strains can assist the tuning of low efficiency transformation protocols as the expression level of some REases may be too low for detection using common approaches. For example, the activity of AvalII in Anabaena sp. PCC7120 was detected only after the application of repeated freeze and thaw cycles (Elhai et al., 1997).

\subsubsection{CRISPR phage immunity system}

Marine cyanobacteria such as the Prochlorococcus and Synechococcus spp. are under a constant threat of phage infection (Mann 2003, Avrani et al., 2011). Cyanophages infecting filamentous heterocystous cyanobacteria seem to be less frequent (Hu et al., 1981). Establishment of transduction as gene transfer system in the laboratory requires lysogenic cyanophages (temperate), such as those that were reported to infect marine Synechococcus strains (McDaniel et al., 2002) and freshwater heterocystous cyanobacteria, however, those are characterized by a narrow host range (Franche 1987). Broad-range temperate cyanophages would provide ideal vectors for cyanobacterial transduction with foreign DNA. For example, the genome sequencing of Chlorogloeopsis fritschii revealed a prophage that could be studied as transduction vector (Dagan et al., 2013). A signature of past phage infection can be recognized within the CRISPR loci (Stern et al., 2012) (Figure 1B). Those comprise an array of conserved repeated sequences separated by sequence spacers of variable length and composition that are flanked by CRISPR-associated (cas) genes (Barrangou et al., 2007). CRISPRs are transcribed to short RNAs (crRNA) that together with the accompanying CAS proteins form a complex that specifically identifies and degrades invading DNA. CRISPR spacers are acquired during phage infection and serve as a recognition sequence for repeating infection by the same phage (reviewed by Sorek et al., 2013). A survey of CRISPR loci in cyanobacterial genomes revealed their presence in 50 out of 54 analyzed genomes (Shih et al., 2013) and there is no doubt that they are widely distributed among cyanobacteria. Active CRISPRs were recently reported in Synechocystis (Scholz et al., 2013). The CRISPR system can also identify and degrade foreign plasmids (Marraffini and Sontheimer 2008).

\subsection{Functional barriers to gene acquisition}

After an exogenous DNA is imported into the cell, the last obstacle for a successful gene acquisition is the functional barrier. The newly incorporated DNA must be able to replicate, either from an autonomously replicative plasmid or by integration into the host genome. Acquired protein coding sequences must be expressed from their own promoter or be inserted downstream an existing promoter in the host genome. In the case of ectopic expression from the replicative vector, the vector must be able to replicate in the cyanobacterial 


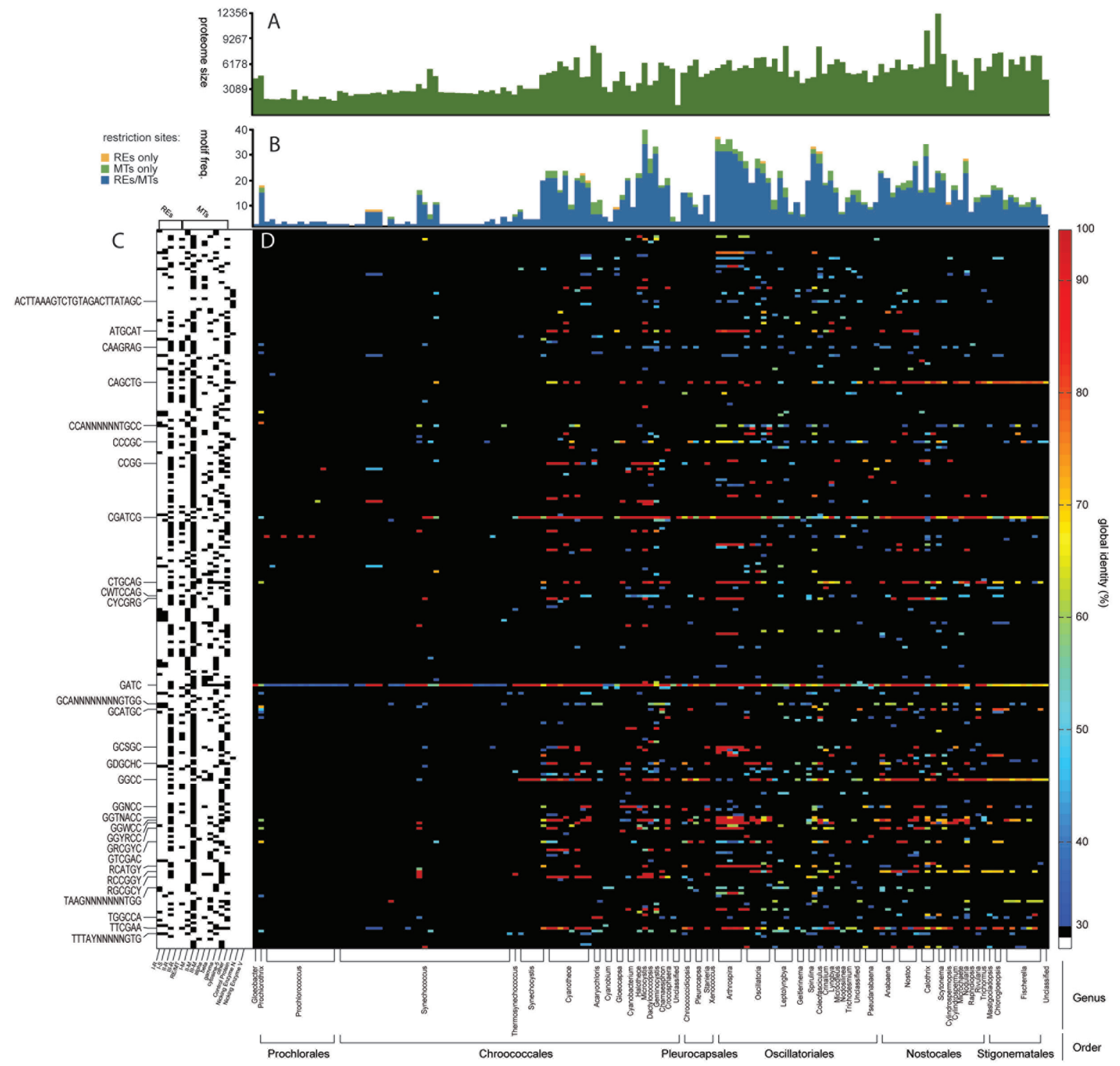

Figure 2. A computational prediction of DNA sequence motifs recognized by RM systems in cyanobacterial genomes. A total of 141 cyanobacterial draft and finished genomes were downloaded from JGI (http://img.jgi.doe.gov/ version of February 2013) and screened for known REases (REs) and MTases (MTs) using a BLAST search (Altschul et al., 1990) with REBASE (Roberts et al., 2010) as a query database. Best BLAST hits for each RE and MT in each genome were identified using a threshold of E-value $\leq 1 \mathrm{E}-07$. These were aligned with their RE/MT query sequence using powerneedle (Rice et al., 2000). A threshold of $30 \%$ global identical amino acids was applied to the resulting pairwise alignments. The resulting dataset has a mean local protein sequence similarity of $43 \pm 11 \%$ to known REs and MTs. (A) A distribution of proteome size in cyanobacterial genomes. Main cyanobacterial genera are listed at the bottom of the figure. (B) The frequency of DNA motifs per genome as predicted by the presence of a corresponding RM system. The stacked bar color corresponds to the RM system components that were detected (see legend) (C) A presence/absence matrix showing the type of REs and MTs (x-axis) found in at least one cyanobacterial genome. The $y$-axis corresponds to unique DNA sequence motifs recognized by RM systems. The most frequent motifs are listed. (D) The distribution of protein sequence similarity to known RM systems. Colored cells in the matrix $M_{i j}$ correspond to detected RM system in genome $i$ (x-axis) having a recognition site $j$ (y-axis). The cell color corresponds to the sequence identity of the most similar homolog to any RM system component found in the genome according to the color bar on the right. 
host. Many cyanobacteria carry plasmids, whose replicons can be used for engineering shuttle vectors for E. coli and cyanobacteria. Such vectors have been designed from Synechocystis, Synechococcus and Anabaena/Nostoc plasmids (Wolk et al., 1984, Golden and Sherman 1984, Buzby et al., 1985, Buikema and Haselkorn 1991, Summers et al., 1995). Among those, plasmids based on the pDU1 replicon from Nostoc sp. PCC 7524 are also able to replicate in cyanobacteria from subsections II, III and V (Billi et al., 2001, Ravindran et al., 2006, Stucken et al., 2012). Furthermore, broad host range RSF1010 (IncQ) based plasmids replicate in most subsection I species and in filamentous strains from subsections III-IV (Elhai and Wolk 1988, Mermet-Bouvier et al., 1993, Haitao and Xudong 2004, Tolonen et al., 2006, Wolk et al., 2007, Min and Sherman 2010, Taton et al., 2012).

Overexpression of foreign DNA or native, but rarely transcribed, genes within the host requires strong or inducible promoters. Cyanobacterial promoters regulated by environmental factors such as copper, iron, nitrogen, inorganic carbon and light as well as promoters adapted from E. coli have been successfully used and are reviewed elsewhere (Heidorn et al., 2011, Ruffing 2011).

If the fate of the exogenous DNA is integration into the host genome by homologous recombination leading to gene replacement or deletion, then double homologous recombination events must occur. A single recombination is used when creating gene-reporter fusions (Elhai and Wolk 1990). This approach usually results in the incorporation of the whole plasmid and has the advantage of studying the gene products under a native regulatory element. This however can also lead to unexpected results depending on the plasmid integration site. This problem could be circumvented by targeting the plasmid insertion to a neutral locus within the chromosome as described for S. elongatus (Bustos and Golden 1992), Synechocystis (Williams 1988, Eisenhut et al., 2012) Synechococcus sp. PCC 7002 (Xu et al., 2011) and Anabaena sp. PCC 7120 (Olmedo-Verd et al., 2005).

The success rates for single and double crossover events depend on the employed strain and the DNA transfer method. Double crossovers are favored over single crossovers in S. elongatus, Synechocystis, and T. elongatus after natural transformation. This is because the DNA is fragmented upon uptake into competent cells and the fragments carrying homologous regions are inserted into the genome (Williams 1988, Chauvat et al., 1989, Labarre et al., 1989, Tsinoremas et al., 1994, Iwai et al., 2004). The opposite is observed after conjugation and electroporation, both promoting single rather then double recombination events (Tsinoremas et al., 1994, Iwai et al., 2004). It may occur that illegitimate recombination events are more frequent than homologous recombination, leading to incorporation of the foreign DNA into non-specific loci. Interestingly, a transformation with ssDNA leads to successful homologous recombination events in Cyanothece sp. strain ATCC 51142 (Min and Sherman 2010). Lower rates of double crossovers are also observed in Anabaena sp. PCC 7120, where the use of a positive selection marker such as $s a c B$, is the most effective way to detect double recombinants (Cai and Wolk 1990). Several other positive selection markers exist for bacteria, among them, lethal genes (Young-Jun et al., 2002) but they have not been yet implemented in cyanobacteria.

Segregation of the newly acquired inserted DNA fragments is also hampered by ploidy of cyanobacteria since most taxa carry multiple copies of their chromosome. Recent studies using Real-Time qPCR have shown that the number of chromosomes can increase to 218 copies in Synechocystis at exponential growth phase (Griese et al., 2011), this is the highest number of genome copies reported so far. Ploidy levels of cyanobacteria have been estimated between 8-72 (Herdman et al., 1979). The number of chromosome copies as most characters discussed in this review, is organism-dependent, but given that polyploidy is a common feature among cyanobacterial strains, several growth cycles can be expected prior to a complete segregation of the investigated character.

Application of systems that increase homologous recombination rates would improve genome manipulation in cyanobacteria. New vectors for recombineering (recombinationmediated genetic engineering (Ellis et al., 2001) are being designed for cyanobacteria (Court et al., 2010). These vectors use the recombination machinery from the prophage lambda, promoting recombination of 30-50 bp regions, and stability of linear DNA fragments (PCR products) or plasmids (Yu et al., 2000). Recently the use of a cas gene and a guiding RNA from CRISPR were shown to promote targeted chromosome dsDNA breakage leading to 130 fold increase in double homologous recombination rates in yeast (DiCarlo et al., 2013). The use of these systems would require that the cyanobacteria are transformable, even at low rates. These are, however, promising systems to increase the rate of double crossover events during knockout generation, and if efficient enough they could increase the number of target chromosome copies of polyploid cyanobacteria, accelerating the segregation process.

\section{CONCLUDING REMARKS}

The availability of more than 140 cyanobacterial genomes, representing a broad range of morphological diversity, environmental and cellular traits is a first stepping-stone in the choice of a novel cyanobacterium as model organism. Existing genetic manipulation tools developed for model cyanobacteria have been successfully employed in many cyanobacterial strains. Thus, gene transfer methods need not to be developed anew, they can however, be modified by pretreatment of the target cells and of foreign DNA before the transfer. Previous knowledge of the defense mechanisms of the strain of interest will contribute to the development of optimized protocols. Bacteriophage vectors that import the DNA via transduction and techniques such as recombineering are promising approaches for future developments. The development of new plasmids carrying different inducible promoters and fusion tags will facilitate further advance in cyanobacterial genetic manipulations.

The incorporation of the available information on promoters, gene fusions, plasmids, and the development of new building blocks or BioBricks available for all interested scientists would help to maintain continuity and sustainability of cyanobacterial molecular biology research and contribute in the development of improved or synthetic cyanobacterial strains with streamlined metabolism for production of high value products for biotechnological, industrial and medical applications.

\section{ACKNOWLEDGEMENTS}

We thank Marion Eisenhut and Giddy Landan for critical comments on the manuscript and Svetlana Kilian for the 
artwork of Figure 1. This work was financed by an ERC grant EVOLATERAL (No. 281357). RK was supported by an ENorm scholarship from the Heinrich-Heine University of Düsseldorf.

\section{REFERENCES}

ABED RMM, DOBRETSOV S, SUDESH K (2009) Applications of cyanobacteria in biotechnology. J App Microbiol 106:1-12

ADHIKARY SP, WECKESSER J, JÜRGENS UJ, GOLECKI JR, BOROWIAK D (1986) Isolation and chemical characterization of the sheath from the cyanobacterium Chroococcus minutus SAG B.41.79. J Gen Microbiol 132:2595-2599

ALTSCHUL SF, GISH W, MILLER W, MYERS EW, LIPMAN DJ (1990) Basic local alignment search tool. J Mol Biol 215:403-410

ARBER W, DUSSOIX D (1962) Host specificity of DNA produced by Escherichia coli: I. Host controlled modification of bacteriophage $\lambda$. J Mol Biol 5:18-36

ARBER W, LINN S (1969) DNA modification and restriction. Ann Rev Biochem 38: 467-500

AVRANI S, WURTZEL O, SHARON I, SOREK R, LINDELL D (2011) Genomic island variability facilitates Prochlorococcus-virus coexistence. Nature 474:604-608

BARRANGOU R, FREMAUX C, DEVEAU H, RICHARDS M, BOYAVAL P, MOINEAU S, ROMERO DA, HORVATH P (2007) CRISPR provides acquired resistance against viruses in prokaryotes. Science 315:1709-1712

BAZIN MJ (1968) Sexuality in a blue-green alga: genetic recombination in Anacystis nidulans. Nature 218: 282-283

BERTOCCHI C, NAVARINI L, CESÀRO A, ANASTASIO M (1990) Polysaccharides from cyanobacteria. Carbohydr Polym 12:127-153

BHAYA D, TAKAHASHI A, GROSSMAN AR (2001) Light regulation of type IV pilus-dependent motility by chemosensor-like elements in Synechocystis PCC6803. Proc Natl Acad Sci USA 98:7540-7545

BILLI D, FRIEDMANN EI, HELM RE, POTTS M (2001) Gene transfer to the desiccation-tolerant cyanobacterium Chroococcidiopsis. J Bacteriol 183:2298-2305

BISCHOFBERGER N, NG PG, WEBB TR, MATTEUCCI MD (1987) Cleavage of single stranded oligonucleotides by EcoRI restriction endonuclease. Nucleic Acids Res 15:709-716

BUIKEMA WJ, HASELKORN R (1991) Isolation and complementation of nitrogen fixation mutants of the cyanobacterium Anabaena sp. strain PCC 7120. J Bacteriol 173:1879-1885

BUSTOS SA, GOLDEN SS (1992) Light-regulated expression of the $p s b D$ gene family in Synechococcus sp. strain PCC 7942: evidence for the role of duplicated $p s b D$ genes in cyanobacteria. Mol Gen Genet 232:221-230

BUZBY JS, PORTER RD, STEVENS SE Jr (1985) Expression of the Escherichia coli lacZ gene on a plasmid vector in a cyanobacterium. Science 230:805-807

CAI YA, WOLK CP (1990) Use of a conditionally lethal gene in Anabaena sp. strain PCC 7120 to select for double recombinants. J Bacteriol 172:3138-3145

CAO J, XU Z, QIU G, LI B (1999) Effects of $\mathrm{Mg}^{2+}$ on the growth and DNase activity of Spirulina platensis, a cyanobacterium. Bioresource Technol 67:287-290

CARPENTER EJ, ROMANS K (1991) Major role of the cyanobacterium Trichodesmium in nutrient cycling in the North Atlantic Ocean. Science 254:1356-1358

CHAUVAT F, ROUET P, BOTTIN H, BOUSSAC A (1989) Mutagenesis by random cloning of an Escherichia coli kanamycin resistance gene into the genome of the cyanobacterium Synechocystis PCC 6803: selection of mutants defective in photosynthesis. Molec Gen Genet 216:51-59

CHEN I, DUBNAU D (2004) DNA uptake during bacterial transformation. Nat Rev Micro 2:241-249

CHEN I, CHRISTIE PJ, DUBNAU D (2005) The ins and outs of DNA transfer in bacteria. Science 310:1456-1460

CLERICO EM, DITTY JL, GOLDEN SS (2007) Specialized techniques for sitedirected mutagenesis in cyanobacteria. In: ROSATO E (ed) Methods in Molecular Biology ${ }^{\mathrm{TM}}$. Humana Press, Totowa, NJ, p 155-171

COURT DL, DATTA S, CONSTANTINO N (2010) Plasmids and phages for homologous recombination and methods of use. U.S. Patent 7,674,621, issued March 09, 2010. US Washington DC.

DAGAN T, ROETTGER M, STUCKEN K, LANDAN G, KOCH R, MAJOR P, GOULD SB, GOREMYKIN VV, RIPPKA R, DE MARSAC NT, GUGGER M, LOCKHART PJ, ALLEN JF, BRUNE I, MAUS I, PÜHLER A, MARTIN WF (2013) Genomes of stigonematalean cyanobacteria (Subsection V) and the evolution of oxygenic photosynthesis from prokaryotes to plastids. Genome Biol Evol 5:35-44
DE PHILIPPIS R, VINCENZINI M (1998) Exocellular polysaccharides from cyanobacteria and their possible applications. FEMS Microbiol Rev 22:151-175

DE PHILIPPIS R, COLICA G, MICHELETTI E (2011) Exopolysaccharideproducing cyanobacteria in heavy metal removal from water: molecular basis and practical applicability of the biosorption process. Appl Microbiol Biotechnol 92:697-708

DE PHILIPPIS R, ENA A, PAPERI R, SILI C, VINCENZINI M (2000) Assessment of the potential of Nostoc strains from the Pasteur Culture Collection for the production of polysaccharides of applied interest. J App Phycol 12:401-407

DICARLO JE, NORVILLE JE, MALI P, RIOS X, AACH J, CHURCH GM (2013) Genome engineering in Saccharomyces cerevisiae using CRISPRCas systems. Nucleic Acids Res 41:4336-4343

DITTMANN E, NEILAN BA, ERHARD M, DÖHREN VON H, BÖRNER $T$ (1997) Insertional mutagenesis of a peptide synthetase gene that is responsible for hepatotoxin production in the cyanobacterium Microcystis aeruginosa PCC 7806. Mol Microbiol 26:779-787

DOOLITTLE WF (1999) Phylogenetic classification and the universal tree. Science 284:2124-2128

DUGGAN PS, GOTTARDELLO P, ADAMS DG (2007) Molecular analysis of genes in Nostoc punctiforme Involved in pilus biogenesis and plant infection. J Bacteriol 189:4547-4551

EISENHUT M, GEORG J, KLAHN S, SAKURAI I, MUSTILA H, ZHANG P, HESS WR, ARO EM (2012) The antisense RNA As1_flv4 in the cyanobacterium Synechocystis sp. PCC 6803 prevents premature expression of the flv4-2 operon upon shift in inorganic carbon supply. J Biol Chem 287:33153-33162

ELHAI J, WOLK CP (1988) A versatile class of positive-selection vectors based on the nonviability of palindrome-containing plasmids that allows cloning into long polylinkers. Genetics 68:119-138

ELHAI J, WOLK CP (1990) Developmental regulation and spatial pattern of expression of the structural genes for nitrogenase in the cyanobacterium Anabaena. ЕMBO J 9:3379-3388

ELHAI J, KATO M, COUSINS S, LINDBLAD P, COSTA JL (2008) Very small mobile repeated elements in cyanobacterial genomes. Genome Res 18:1484-1499

ELHAI J, VEPRITSKIY A, MURO-PASTOR AM, FLORES E, WOLK CP (1997) Reduction of conjugal transfer efficiency by three restriction activities of Anabaena sp. PCC 7120. J Bacteriol 179:1998-2005

ELLIS HM, YU D, DITIZIO T, COURT DL (2001) High efficiency mutagenesis, repair, and engineering of chromosomal DNA using single-stranded oligonucleotides. Proc Natl Acad Sci USA 98:6742-6746

FATTOM A, SHILO M (1984) Hydrophobicity as an adhesion mechanism of benthic cyanobacteria. Appl Environ Microbiol 74:135-143

FISCHER D, SCHLÖSSER UG, POHL P (1997) Exopolysaccharide production by cyanobacteria grown in closed photobioreactors and immobilized using white cotton towelling. J Appl Phycol 9:205-213

FLAIBANI A, OLSEN Y, PAINTER TJ (1989) Polysaccharides in desert reclamation: compositions of exocellular proteoglycan complexes produced by filamentous blue-green and unicellular green edaphic algae. Carbohydr Res 190:235-248

FLEMMING HC, WINGENDER J (2010) The biofilm matrix. Nat Rev Micro 8:623-633

FRANCHE C (1987) Isolation and characterization of a temperate cyanophage for a tropical Anabaena strain. Arch Microbiol 148:172-177

FRANGEUL L, QUILLARDET P, CASTETS A-M, HUMBERT J-F, MATTHIJS HC, CORTEZ D, TOLONEN A, ZHANG C-C, GRIBALDO S, KEHR J-C, ZILLIGES Y, ZIEMERT N, BECKER S, TALLA E, LATIFI A, BILLAULT A, LEPELLETIER A, DITTMANN E, BOUCHIER C, TANDEAU DE MARSAC N (2008) Highly plastic genome of Microcystis aeruginosa PCC 7806, a ubiquitous toxic freshwater cyanobacterium. BMC Genomics 9:274

FREITAS F, ALVES VD, REIS MAM (2011) Advances in bacterial exopolysaccharides: from production to biotechnological applications. Trends in Biotechnol 29:388-398

GLOAGUEN V, MORVAN H, HOFFMANN L, PLANCKE Y, WIERUSZESKI JM, LIPPENS G, STRECKER G (1999) Capsular polysaccharide produced by the thermophilic cyanobacterium Mastigocladus laminosus. Eur J Biochem 266:762-770

GOGARTEN JP, TOWNSEND JP (2005) Horizontal gene transfer, genome innovation and evolution. Nat Rev Micro 3:679-687

GOLDEN SS, SHERMAN LA (1984) Optimal conditions for genetic transformation of the cyanobacterium Anacystis nidulans R2. J Bacteriol 158:36-42

GRIESE M, LANGE C, SOPPA J (2011) Ploidy in cyanobacteria. FEMS Microbiol Lett 323:124-131 
GRIGORIEVA G, SHESTAKOV S (1982) Transformation in the cyanobacterium Synechocystis sp. 6803. FEMS Microbiol Lett 13:367-370

GROßKOPF T, LAROCHE J (2012) Direct and indirect costs of dinitrogen fixation in Crocosphaera watsonii WH8501 and possible implications for the nitrogen cycle. Front Microbiol 3:236

HAITAO G, XUDONG X (2004) Broad host range plasmid-based gene transfer system in the cyanobacterium Gloeobacter violaceus which lacks thylakoids. Prog Nat Sci 14:31-35

HEIDORN T, CAMSUND D, HUANG H-H, LINDBERG P, OLIVEIRA P, STENSJÖ K, LINDBLAD P (2011) Synthetic biology in cyanobacteria: engineering and analyzing novel functions. Methods Enzymol 497:539-579

HERDMAN M, JANVIER M, RIPPKA R, STANIER RY (1979) Genome size of cyanobacteria. J Gen Microbiol 11:73-75

HOICZYK E (2000) Gliding motility in cyanobacteria: observations and possible explanations. Arch Microbiol 174:11-17

HOICZYK E, BAUMEISTER W (1995) Envelope structure of four gliding filamentous cyanobacteria. J Bacteriol 177:2387-2395

HOICZYK E, BAUMEISTER W (1998) The junctional pore complex, a prokaryotic secretion organelle, is the molecular motor underlying gliding motility in cyanobacteria. Curr Biol 8:1161-1168

HOICZYK E, HANSEL A (2000) Cyanobacterial cell walls: news from an unusual prokaryotic envelope. J Bacteriol 182:1191-1199

HORIUCHI K, ZINDER ND (1975) Site-specific cleavage of single-stranded DNA by a Hemophilus restriction endonuclease. Proc Natl Acad Sci USA 72:2555-2558

HOUGH L, JONES JKN, WADMAN WH (1952) An investigation of the polysaccharide components of certain fresh-water algae. J Chem Soc 3393-3399

HU N-T, THIEL T, GIDDINGS TH JR, WOLK CP (1981) New Anabaena and Nostoc cyanophages from sewage settling ponds. Virology 114:236-246

IWAI M, KATOH H, KATAYAMA M, IKEUCHI M (2004) Improved genetic transformation of the thermophilic cyanobacterium, Thermosynechococcus elongatus BP-1. Plant Cell Physiol 45:171-175

JONES CS, MAYFIELD SP (2012) Algae biofuels: versatility for the future of bioenergy. Curr Op Biotechnol 23:346-351

KLEIN TM, FITZPATRICK-MCELLIOT S (1993) Particle bombardment: a universal approach for gene transfer to cells and tissues. Curr Op Biotechnol 4:583-590

KLINT J, RAN L, RASMUSSEN U, BERGMAN B (2006) Identification of developmentally regulated proteins in cyanobacterial hormogonia using a proteomic approach. Symbiosis 41:87-95

KUFRYK GI, SACHET M, SCHMETTERER G, VERMAAS WFJ (2002) Transformation of the cyanobacterium Synechocystis sp. PCC 6803 as a tool for genetic mapping: optimization of efficiency. FEMS Microbiol Lett 206:215-219

KUMAR HD (1962) Apparent genetic recombination in a blue-green alga. Nature 196:1121-1122

LABARRE J, CHAUVAT F, THURIAUX P (1989) Insertional mutagenesis by random cloning of antibiotic resistance genes into the genome of the cyanobacterium Synechocystis strain PCC 6803. J Bacteriol 171:3449-3457

LABRIE SJ, SAMSON JE, MOINEAU S (2010) Bacteriophage resistance mechanisms. Nat Rev Micro 8:317-327

LÜRLING M, FASSIL E, FAASEEN EJ, KOSTEN S, HUSZAR VLM (2013) Comparison of cyanobacterial and green algal growth rates at different temperatures. Freshwater Biol 58:552-559

LYRA C, HALME T, TORSTI AM, TENKANEN T, KAARINA S (2000) Sitespecific restriction endonucleases in cyanobacteria. J Appl Microbiol 89:979-991

MANN NH (2003) Phages of the marine cyanobacterial picophytoplankton. FEMS Microbiol Rev 27:17-34

MARRAFFINI LA, SONTHEIMER EJ (2008) CRISPR interference limits horizontal gene transfer in Staphylococci by targeting DNA. Science 322:1843-1845

MASUKAWA H, KITASHIMA M, INOUE K, SAKURAI H, HAUSINGER R (2012) Genetic engineering of cyanobacteria to enhance biohydrogen production from sunlight and water. AMBIO 41:169-173

MAZOR G, KIDRON GJ, VONSHAK A, ABELIOVICH A (1996) The role of cyanobacterial exopolysaccharides in structuring desert microbial crusts. FEMS Microbiol Ecol 21:121-130

MCDANIEL L, HOUCHIN LA, WILLIAMSON SJ, PAUL JH (2002) Plankton blooms: Lysogeny in marine Synechococcus. Nature 415:496-496

MEEKS JC, ELHAI J (2002) Regulation of cellular differentiation in filamentous cyanobacteria in free-living and plant-associated symbiotic growth states. Microbiol Mol Biol Rev 66:94-121

MERINO-PUERTO V, MARISCAL V, MULLINEAUX CW, HERRERO A, FLORES E (2010) Fra proteins influencing filament integrity, diazotrophy and localization of septal protein SepJ in the heterocystforming cyanobacterium Anabaena sp. Mol Microbiol 75:1159-1170

MERMET-BOUVIER P, CASSIER-CHAUVAT C, MARRACCINI P, CHAUVAT F (1993) Transfer and replication of RSF1010-derived plasmids in several cyanobacteria of the genera Synechocystis and Synechococcus. Curr Microbiol 27:323-327

MIN H, SHERMAN LA (2010) Genetic transformation and mutagenesis via single-stranded DNA in the unicellular, diazotrophic cyanobacteria of the genus Cyanothece. Appl Environ Microbiol 76:7641-7645

MULKIDJANIAN AY, KOONIN EV, MAKAROVA KS, MEKHEDOV SL, SOROKIN A, WOLF YI, DUFRESENE A, PARTENSKY F, BURD H, KAZNADZEY D, HASELKORN R, GALPERIN MY (2006) The cyanobacterial core genome and the origin of photosynthesis. Proc Natl Acad Sci USA 103:13126-13131

NAKASUGI K, NEILAN BA (2005) Identification of pilus-like structures and genes in Microcystis aeruginosa PCC7806. Appl Environ Microbiol 71:7621-7625

NAKASUGI K, ALEXOVA R, SVENSON CJ, NEILAN BA (2007) Functional analysis of PilT from the toxic cyanobacterium Microcystis aeruginosa PCC 7806. J Bacteriol 189:1689-1697

NAKASUGI K, SVENSON CJ, NEILAN BA (2006) The competence gene, comf, from Synechocystis sp. strain PCC 6803 is involved in natural transformation, phototactic motility and piliation. Microbiology 152:3623-3631

NICOLAUS B, PANICO A, LAMA L, ROMANO I, MANCA MC, DE GUILIO A, GAMBACORTA A (1999) Chemical composition and production of exopolysaccharides from representative members of heterocystous and non-heterocystous cyanobacteria. Phytochemistry 52:639-647

NISHIGAKI K, KANEKO Y, WAKUDA H, HUSIMI Y, TANAKA T (1985) Type II restriction endonucleases cleave single-stranded DNAs in general. Nucleic Acids Res 13:5747-5760

OKAMOTO S, OHMORI M (2002) The cyanobacterial PilT protein responsible for cell motility and transformation hydrolyzes ATP. Plant Cell Physiol 43:1127-1136

OLMEDO-VERD E, FLORES E, HERRERO A, MURO-PASTOR AM (2005) HetR-dependent and -independent expression of heterocyst-related genes in an Anabaena strain overproducing the NtcA transcription factor. J Bacteriol 187:1985-1991

ONAI K, TABATA S, ISHIURA M, KANEKO T, MORISHITA M (2004) Natural transformation of the thermophilic cyanobacterium Thermosynechococcus elongatus BP-1: a simple and efficient method for gene transfer. Mol Gen Genomics 271:50-59

PANOFF JM, PRIEM B, MORVAN H, JOSET F (1988) Sulphated exopolysaccharides produced by two unicellular strains of cyanobacteria, Synechocystis PCC 6803 and 6714. Arch Microbiol 150:558-563

PARTENSKY F, HESS WR, VAULOT D (1999) Prochlorococcus, a marine photosynthetic prokaryote of global significance. Microbiol Mol Biol Rev 63:106-127

PEREIRA S, ZILLE A, MICHELETTI E, MORADAS-FERREIRA P, DE PHILIPPIS R, TAMAGNINI P (2009) Complexity of cyanobacterial exopolysaccharides: composition, structures, inducing factors and putative genes involved in their biosynthesis and assembly. FEMS Microbiol Rev 33:917-941

POPA O, DAGAN T (2011) Trends and barriers to lateral gene transfer in prokaryotes. Curr Op Microbiol 14:615-623

PRITZER M, WECKESSER J, JÜRGENS UJ (1989) Sheath and outer membrane components from the cyanobacterium Fischerella sp. PCC 7414. Arch Microbiol 153:7-11

PROTEAU PJ, GERWICK WH, GARCIA-PICHEL F, CASTENHOLZ R (1993) The structure of scytonemin, an ultraviolet sunscreen pigment from the sheaths of cyanobacteria. Experientia 49:825-829

QUINTANA N, KOOY F, RHEE M, VOSHOL G, VERPOORTE R (2011) Renewable energy from cyanobacteria: energy production optimization by metabolic pathway engineering. Appl Microbiol Biotechnol 91:471-490

RAMUS J (1977) Alcian blue: a quantitative aqueous assay for algal acid and sulfated polysaccharides. J Phycol 13:345-348

RAVINDRAN CRM, SUGUNA S, SHANMUGASUNDARAM S (2006) Electroporation as a tool to transfer the plasmid pRL489 in Oscillatoria MKU 277. J Microbiol Methods 66:174-176

RAYMOND J, ZHAXYBAYEVA O, GOGARTEN PJ, GERDES SY, BLANKENSHIP RE (2002) Whole-genome analysis of photosynthetic prokaryotes. Science 298:1616-1620

RICE P, LONGDEN I, BLEASBY A (2000) EMBOSS: the European Molecular Biology Open Software Suite. Trends Genet 16:276-277 
RIPPKA R, DERUELLES J, WATERBURY JB, HERDMAN M, STANIER RY (1979) Generic assignments, strain histories and properties of pure cultures of cyanobacteria. J Gen Microbiol 111:1-61

ROBERTS RJ (2003) A nomenclature for restriction enzymes, DNA methyltransferases, homing endonucleases and their genes. Nucleic Acids Res 31:1805-1812

ROBERTS RJ, VINCZE T, POSFAI J, MACELIS D (2010) REBASEdatabase for DNA restriction and modification: enzymes, genes and genomes. Nucleic Acids Res 38:D234-D236

RUFFING AM (2011) Engineered cyanobacteria: teaching an old bug new tricks. Bioeng Bugs 2:136-149

SANGAR VK, DUGAN PR (1972) Polysaccharide produced by Anacystis nidulans: its ecological implication. Appl Microbiol 24:732-734

SCHADER M, DREWS G, GOLECKI JR, WECKESSER J (1982) Isolation and characterization of the sheat from the cyanobacterium Chlorogloeopsis PCC 6912. J Gen MIcrobiol128:267-272

SCHOLZ I, LANGE SJ, HEIN S, HESS WR, BACKOFEN R (2013) CRISPRCas systems in the cyanobacterium Synechocystis sp. PCC6803 exhibit distinct processing pathways involving at least two Cas6 and a Cmr2 protein. PLoS ONE 8:e56470

SHESTAKOV SV, THAN KHYEN N (1970) Evidence for genetic transformation in blue-green alga Anacystis nidulans. Mol Gen Genet 107:372-375

SHIH PM, WU D, LATIFI A, AXEN SD, FEWER DP, TALLA E, CALTEAU A, CAI F, TANDEAU DE MARSAC N, RIPPKA R, HERDMAN M, SIVONEN K, COURSIN T, LAURENT T, GOODWIN L, NOLAN M, DAVENPORT KW, HAN CS, RUBIN EM, EISEN JA, WOYKE T, GUGGER M, KERFELD CA (2013) Improving the coverage of the cyanobacterial phylum using diversity-driven genome sequencing. Proc Natl Acad Sci USA 110:1053-1058

SOPER BW, REDDY KJ (1994) Identification of a nuclease and host restriction-modification in the unicellular, aerobic nitrogen-fixing cyanobacterium Cyanothece sp. J Bacteriol 176:5565-5570

SOPER BW, HOLLISTER WR, REDDY KJ (1996) Characterization of additional host restriction-modification systems in the unicellular cyanobacterium Cyanothece sp. Biochem Biophys Res Commun 223:24-30

SOREK R, LAWRENCE CM, WIEDENHEFT B (2013) CRISPR-mediated adaptive immune systems in bacteria and archaea. Annu Rev Biochem $82: 237-266$

STERN A, MICK E, TIROSH I, SAGY O, SOREK R (2012) CRISPR targeting reveals a reservoir of common phages associated with the human gut microbiome. Genome Res 22:1985-1994

STEVENS SE, PORTER RD (1980) Transformation in Agmenellum quadruplicatum. Proc Natl Acad Sci USA 77:6052-6056

STUCKEN K, ILHAN J, ROETTGER M, DAGAN T, MARTIN W (2012) Transformation and conjugal transfer of foreign genes into the filamentous multicellular cyanobacteria (Subsection V) Fischerella and Chlorogloeopsis. Curr Microbiol 65:552-560

SUMMERS ML, WALLIS JG, CAMPBELL EL, MEEKS JC (1995) Genetic evidence of a major role for glucose-6-phosphate dehydrogenase in nitrogen fixation and dark growth of the cyanobacterium Nostoc sp. strain ATCC 29133. J Bacteriol 177:6184-6194
SUTHERLAND IW (2001) Biofilm exopolysaccharides: a strong and sticky framework. Microbiol 147:3-9

TAKAHASHI I, HAYANO D, ASAYAMA M, MASAHIRO F, WATAHIKI M, SHIRAI M (1996) Restriction barrier composed of an extracellular nuclease and restriction endonuclease in the unicellular cyanobacterium Microcystis sp. FEMS Microbiol Lett 145:107-111

TATON A, LIS E, ADIN DM, DONG G, COOKSON S, KAY SA, GOLDEN SS, GOLDEN JW (2012) Gene transfer in Leptolyngbya sp. Strain BL0902, a cyanobacterium suitable for production of biomass and bioproducts. PLOS ONE 7:e30901

THIEL T, POO H (1989) Transformation of a filamentous cyanobacterium by electroporation. J Bacteriol 171:5743-5746

THOMAS CM, NIELSEN KM (2005) Mechanisms of, and barriers to, horizontal gene transfer between bacteria. Nat Rev Micro 3:711-721

TOLONEN AC, LISZT GB, HESS WR (2006) Genetic manipulation of Prochlorococcus strain MIT9313: green fluorescent protein expression from an RSF1010 plasmid and Tn5 transposition. Appl Environ Microbiol 72:7607-7613

TREHAN K, SINHA U (1982) DNA-mediated transformation in Nostoc muscorum, a nitrogen-fixing cyanobacterium. Aust J Biol Sci 35:573-578

TSINOREMAS NF, KUTACH AK, STRAYER CA, GOLDEN SS (1994) Efficient gene transfer in Synechococcus sp. strains PCC 7942 and PCC 6301 by interspecies conjugation and chromosomal recombination. J Bacteriol 176:6764-6768

VAN MELDEREN L (2010) Toxin-antitoxin systems: why so many, what for? Curr Op Microbiol 13:781-785

VASU K, NAGARAJA V (2013) Diverse functions of restriction-modification systems in addition to cellular defense. Microbiol Mol Biol Rev 77:53-72

VINCENZINI M, PHILIPPIS R, SILI C, MATERASSI R (1990) Studies on exopolysaccharide release by diazotrophic batch cultures of Cyanospira capsulata. Appl Microbiol Biotechnol 34:392-396

WILLIAMS JGK (1988) Construction of specific mutations in photosystem II photosynthetic reaction center by genetic engineering methods in Synechocystis 6803 Methods Enzymol 168:766-1778

WOLK CP, KRAUS J (1982) Two approaches to obtaining low, extracellular deoxyribonuclease activity in cultures of heterocyst-forming cyanobacteria. Arch Microbiol 131:302-307

WOLK CP, FAN Q, ZHOU R, HUANG G, LECHNO-YOSSEF S, KURITZ T, WOJCIUCH E (2007) Paired cloning vectors for complementation of mutations in the cyanobacterium Anabaena sp. strain PCC 7120. Arch Microbiol 188:551-563

WOLK CP, VONSHAK A, KEHOE P, ELHAI J (1984) Construction of shuttle vectors capable of conjugative transfer from Escherichia coli to nitrogenfixing filamentous cyanobacteria. Proc Natl Acad Sci USA 81:1561-1565

YOSHIHARA S, GENG XX, OKAMOTO S, YURA K, MURATA T, GO M, OHMORI M, IKEUCHI M (2001) Mutational analysis of genes involved in pilus structure, motility and transformation competency in the unicellular motile cyanobacterium Synechocystis sp. PCC 6803. Plant Cell Physiol 42:63-73

YOUNG-JUN C, TSUNG-TSAN W, LEE BH (2002) Positive selection vectors. Crit Rev Biotechnol 22:225-244

YU D, ELLIS HM, LEE E-C, JENKINS NA, COPELAND NG, COURT DL (2000) An efficient recombination system for chromosome engineering in Escherichia coli. Proc Natl Acad Sci USA 97:5978-5983 